Article

\title{
Prevention of Barite Sag in Oil-Based Drilling Fluids Using a Mixture of Barite and Ilmenite as Weighting Material
}

\author{
Abdelmjeed Mohamed ${ }^{(D)}$, Salem Basfar ${ }^{\mathbb{D}}$, Salaheldin Elkatatny *(D) and Abdulaziz Al-Majed \\ College of Petroleum Engineering and Geosciences, King Fahd University of Petroleum \& Minerals, \\ 31261 Dhahran, Saudi Arabia; abdelmjeed.mohamed@kfupm.edu.sa (A.M.); g201407960@kfupm.edu.sa (S.B.); \\ aamajed@kfupm.edu.sa (A.A.-M.) \\ * Correspondence: elkatatny@kfupm.edu.sa
}

Received: 16 September 2019; Accepted: 10 October 2019; Published: 12 October 2019

check for updates

\begin{abstract}
Drilling high-pressure high-temperature (HPHT) wells requires a special fluid formulation that is capable of controlling the high pressure and is stable under the high downhole temperature. Barite-weighted fluids are common for such purpose because of the good properties of barite, its low cost, and its availability. However, solids settlement is a major problem encountered with this type of fluids, especially at elevated downhole temperatures. This phenomenon is known as barite sag, and it is encountered in vertical and directional wells under static or dynamic conditions leading to serious well control issues. This study aims to evaluate the use of barite-ilmenite mixture as a weighting agent to prevent solids sag in oil-based muds at elevated temperatures. Sag test was conducted under static conditions (vertical and inclined) at $350{ }^{\circ} \mathrm{F}$ and under dynamic conditions at $120^{\circ} \mathrm{F}$ to determine the optimum ilmenite concentration. Afterward, a complete evaluation of the drilling fluid was performed by monitoring density, electrical stability, rheological and viscoelastic properties, and filtration performance to study the impact of adding ilmenite on drilling fluid performance. The results of this study showed that adding ilmenite reduces sag tendency, and only $40 \mathrm{wt} . \%$ ilmenite (from the total weighting material) was adequate to eliminate barite sag under both static and dynamic conditions with a sag factor of around 0.51. Adding ilmenite enhanced the rheological and viscoelastic properties and the suspension of solid particles in the drilling fluid, which confirmed sag test results. Adding ilmenite slightly increased the density of the drilling fluid, with a slight decrease in the electrical stability within the acceptable range of field applications. Moreover, a minor improvement in the filtration performance of the drilling fluid and filter cake sealing properties was observed with the combined weighting agent. The findings of this study provide a practical solution to the barite sag issue in oil-based fluids using a combination of barite and ilmenite powder as a weighting agent to drill HPHT oil and gas wells safely and efficiently with such type of fluids.
\end{abstract}

Keywords: weighting materials; barite; ilmenite; barite sag; oil-based drilling fluids; HPHT wells

\section{Introduction}

Weighting material is one of the main drilling fluid additives used to achieve the required density to overbalance formation pressure during drilling operations and prevent any loss of well control [1-4]. In addition to well control, drilling fluids have many other functions, such as circulating the drilled cuttings to the surface and suspending the cuttings while drilling operation is stopped [5] and cooling and lubricating the drill bit to ease the drilling operation [6]. In high-pressure high-temperature applications, a special drilling fluid formulation is required to meet the critical downhole conditions. In such cases, drilling fluids should have a high density to suppress the high formation pressure with good stability at that elevated temperatures [7]. 
High-density weighting materials are introduced to the drilling fluid formulation to provide the required fluid density, such as barite, hematite, manganese tetraoxide, and ilmenite [8-12]. Because of its high specific gravity (4.2-4.4), low production cost, and low environmental impact, barite is a common weighting agent [13-15]. However, solid particle settlement is a common issue while using barite-weighted drilling fluids, and this phenomenon is known as barite sag [16,17]. These settled particles will not contribute to the fluid density, leading to serious well control issues $[18,19]$, and they interfere with drilling and production operations (Figure 1) [7]. Moreover, the accumulated solid particles and drilled cuttings increase the possibility of pipe sticking and decrease the rate of penetration [20]. Barite sag phenomenon may occur in both vertical and directional wells at static and dynamic conditions, and it is more serious under dynamic conditions with a low shear rate [21]. However, maintaining and monitoring drilling fluid rheology and training the drilling rig personnel would mitigate the consequences of solids sag [22].

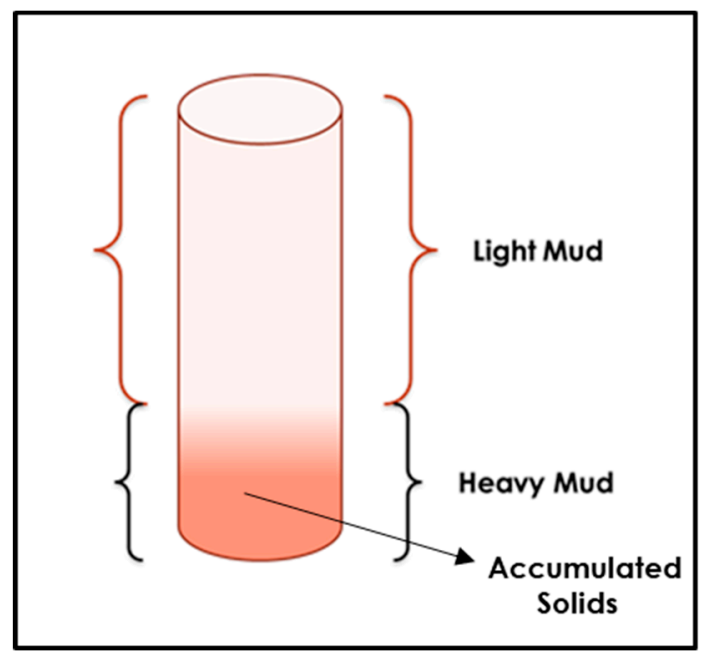

Figure 1. Density variations resulted from solids sag phenomenon [23].

Several laboratory studies were performed to understand and prevent barite sag issue in water and oil-based drilling and completion fluids. Temple et al. [24] proposed a new approach to reduce barite sag in invert emulsion mud by adding a low molecular weight polyalkyl methacrylate. This formulation reduced sag tendency without increasing the viscosity of the drilling fluids, and no copolymer was added. A new drilling fluid formulation with a reduced sag tendency was introduced by Davis et al. [25]. Their formulation consists of invert emulsion mud, barite as a weighting agent, and polyethylene glycol (PEG) as a stability enhancer.

Basfar et al. [26] and Elkatatny [27] performed a study on barite sag prevention in inverted emulsion drilling fluid using copolymer. They found that one $\mathrm{lbm} / \mathrm{bbl}$ of the copolymer was adequate to eliminate solids sag under static and dynamic conditions at $350^{\circ} \mathrm{F}$ downhole temperature. Another study on barite sag prevention in inverted emulsion mud was carried out by Elkatatny [28]. In this study, organophilic phyllosilicate (OP) was used as an anti-sagging agent. He concluded that adding only 1.5 grams of the anti-sagging agent $(\mathrm{OP})$ would solve the solids sag issue under dynamic conditions.

Some other research studies suggest playing with the weighting agent as a solution to the solids sag phenomenon. Mohamed et al. [7] conducted a study on the effect of barite particle size on sag tendency in water-based drilling fluids. They found that reducing the particle size enhances drilling fluid stability and reduces sag tendency, whereas, it did not eliminate the problem. Alabdullatif et al. [29] introduced a new water-based fluid formulation to kill high-pressure high-temperature (HPHT) wells. They used a mixture of barite and manganese tetraoxide $\left(\mathrm{Mn}_{3} \mathrm{O}_{4}\right)$ as weighting material to prevent barite sag. $\mathrm{Mn}_{3} \mathrm{O}_{4}$ was found to be effective in improving drilling fluid stability and reducing barite sag tendency. Abdou et al. [30] studied the effect of ilmenite and barite mixture on drilling fluid density and rheological properties. They concluded that using this mixture yields comparable 
performance to barite, and it could be used as a replacement to barite because of the low solid content and fluid loss that would consequently minimize formation damage.

Basfar et al. [23] evaluated the use of barite-ilmenite mixture as a weighting agent with water-based drilling fluids. It was found that adding ilmenite to barite-weighted drilling fluids enhances the fluid stability and reduces the sag tendency. The optimum ratio of ilmenite to barite was found to be 1 to 1 (50 wt.\% ilmenite from the total weighting material).

As the challenges of drilling operations increase with drilling unconventional reservoirs, several studies were conducted using nanoparticles (NPs) to improve the performance of the drilling operations. NPs improve the performance of the drilling fluid in many ways, such as improving the rheological properties, minimizing friction and fluid filtrate invasion, and enhancing the thermal stability of the drilling fluid at HPHT conditions [31-33]. A study was conducted by Boyou et al. [20] to enhance the suspension capability of the drilling fluid to efficiently transport drilled cuttings and prevent the development of cuttings bed by adding nanosilica in different concentrations to water-based drilling fluids. They evaluated the performance of nan-enhanced water-based fluid in directional drilling operations by conducting an experimental study at different angles of inclination using a flow loop setup. It was concluded that nanosilica particles significantly enhanced the cutting transport efficiency in all inclinations by increasing the colloidal interaction with cuttings.

In addition to the barite sag issue, the high demand and limited resources of barite increase the urge to find another alternative weighting agent to drill HPHT wells [34]. Research work was conducted using ilmenite for this purpose because it has higher specific gravity than barite (4.7-4.79), and it is available and acid-soluble [35-37]. However, the main disadvantage of ilmenite is the abrasiveness to drilling fluid equipment [37], and this can be avoided by optimizing the particle size distribution and using small percentages of large particles $(>45 \mu \mathrm{m})$ not higher than $3 \%$ [34]. While most of the previous studies focused on adding a stability enhancer, polymers, or special additives to solve the sag issue, this study suggests playing with the weighting and adding a mixture of barite and ilmenite to be used as a combined weighting agent in oil-based drilling as a solution to the barite sag issue. Combining ilmenite with barite would eliminate solids sag in barite-weighted drilling fluids to drill HPHT wells efficiently with such fluids, and reduce the high cost of ilmenite-weighted fluids as well. First, the materials used in this study and the experimental procedures are presented. Then, the obtained results are discussed, and finally, the findings and limitations of this study are summarized.

\section{Methodology}

\subsection{Materials}

The invert emulsion mud used in this work was prepared in the lab using a three-speed mud mixer. Diesel was used as the continuous phase of the fluid. Then, additives were added and mixed in order, starting with the primary emulsifier (INVERMUL ${ }^{\circledR}$ ). Lime was used to enhance emulsion stability. To minimize fluid filtrate invasion, a fluid loss control additive (DURATONE ${ }^{\circledR}$ ) and a bridging agent $\left(\mathrm{CaCO}_{3}\right)$ were added. Water was added as the discontinuous phase, GELTONE ${ }^{\circledR} \mathrm{II}$ was used as a viscosifier to maintain the rheology of the drilling fluid [1,2], and EZ MUL ${ }^{\circledR}$ was added as a secondary emulsifier. The high density of the drilling fluid was achieved by adding barite $\left(D_{50}=17 \mu \mathrm{m}\right)$. Several drilling fluid samples were prepared by mixing ilmenite $\left(D_{50}=5 \mu \mathrm{m}\right)$ with barite as a weighting agent. Ilmenite was added in different percentages-20, 40, 60, and $80 \mathrm{wt} . \%$ (from the total weighting material). The particle size distribution for both barite and ilmenite is shown in Figure 2. Tables 1 and 2 show the used fluid formulation and the properties of the base drilling fluid sample. 


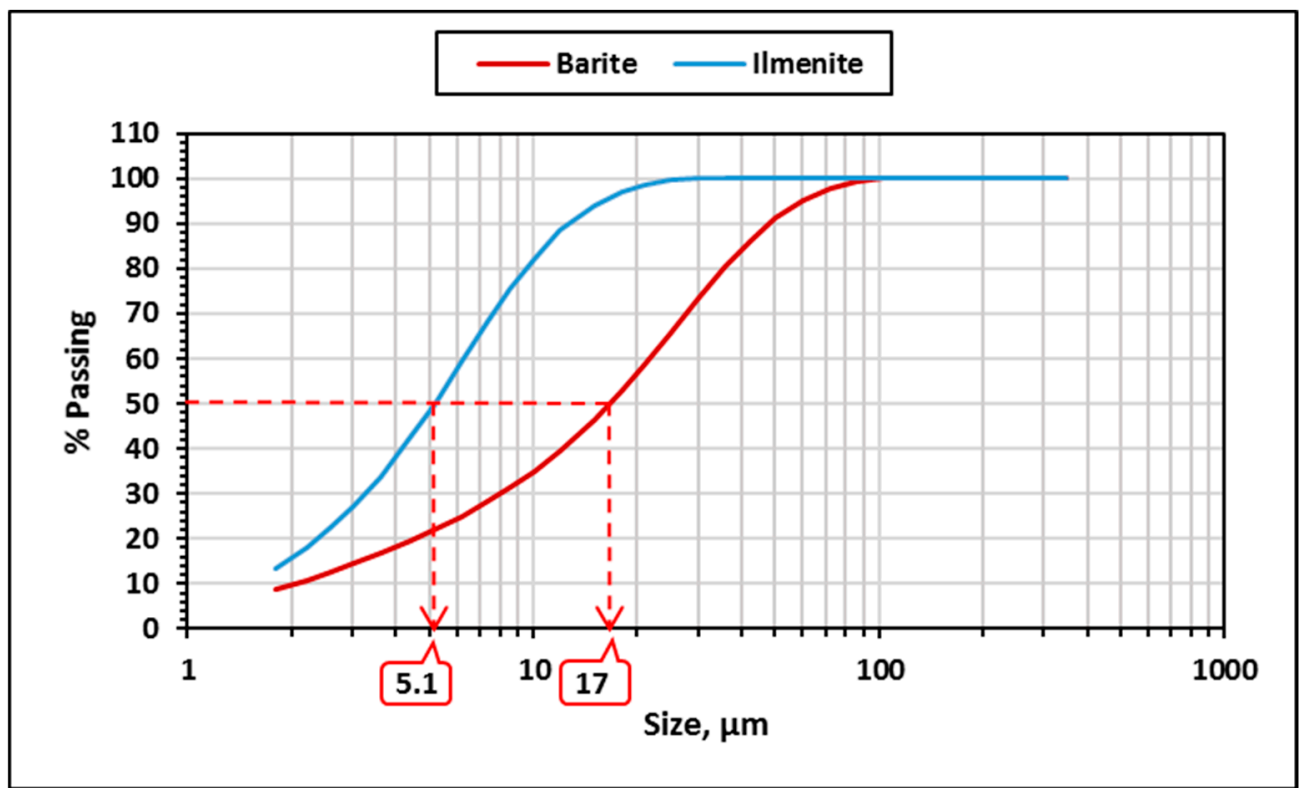

Figure 2. Particle size distribution for the used weighting materials.

Table 1. Drilling fluid formulation used in this study (lab scale).

\begin{tabular}{cc}
\hline Additive & Amount \\
\hline Diesel & $171.5 \mathrm{~mL}$ \\
Primary Emulsifier (INVERMUL ${ }^{\circledR}$ ) & $11 \mathrm{~g}$ \\
Lime & $6 \mathrm{~g}$ \\
Fluid loss control (DURATONE $\left.{ }^{\circledR}\right)$ & $7 \mathrm{~g}$ \\
Water & $49.7 \mathrm{~mL}$ \\
$\mathrm{CaCl}_{2}$ & $32 \mathrm{~g}$ \\
Viscosifier $\left(\mathrm{GELTONE}^{\circledR} \mathrm{II}\right)$ & $10 \mathrm{~g}$ \\
Secondary emulsifier $\left(\mathrm{EZ} \mathrm{MUL}^{\circledR}\right)$ & $4 \mathrm{~g}$ \\
Bridging agent $\left(\mathrm{CaCO}_{3}\right)$ & $30 \mathrm{~g}$ \\
Weighting Material $\left(\mathrm{Barite}^{\mathrm{a}}\right)$ & $300 \mathrm{~g}$ \\
\hline
\end{tabular}

Table 2. Properties of the base drilling fluid at $350^{\circ} \mathrm{F}$.

\begin{tabular}{ccc}
\hline Shear Rate, RPM & \multicolumn{2}{c}{ Shear Stress, D.R. } \\
\hline 600 & \multicolumn{2}{c}{49} \\
300 & \multicolumn{2}{c}{30} \\
200 & \multicolumn{2}{c}{25} \\
100 & \multicolumn{2}{c}{18} \\
6 & 8 \\
3 & 8 \\
Density & 14.5 & $\mathrm{ppg}$ \\
PV & 15 & $\mathrm{cP}$ \\
YP & 18 & $\mathrm{lb} / 100 \mathrm{ft}^{2}$ \\
Gel strength 10 s & 7 & $\mathrm{lb} / 100 \mathrm{ft}^{2}$ \\
Gel strength 10/30 min & $8 / 9$ & $\mathrm{lb} / 100 \mathrm{ft}^{2}$ \\
\hline
\end{tabular}

\subsection{Sag Test}

Sag test was conducted to study the impact of adding ilmenite on solids sag tendency at static and dynamic conditions. The static sag test was performed at vertical and inclined $\left(45^{\circ}\right)$ conditions using an aging cell assembly (Figure 3). Tests were conducted at $350^{\circ} \mathrm{F}$ and 500 psi and run for $24 \mathrm{~h}$. 
Afterward, two fluid samples were taken from the top and the bottom of the cell using a syringe, and the density of both samples was measured. Equation (1) was used to calculate the sag factor.

$$
\text { Sag Factor }=\frac{\rho_{\text {Bottom }}}{\rho_{\text {Bottom }}+\rho_{\text {Top }}}
$$

$\rho_{\text {Bottom }}, \rho_{\text {Top }}=$ the density (in ppg) of the fluid samples taken from the bottom and the top of the cell, respectively.

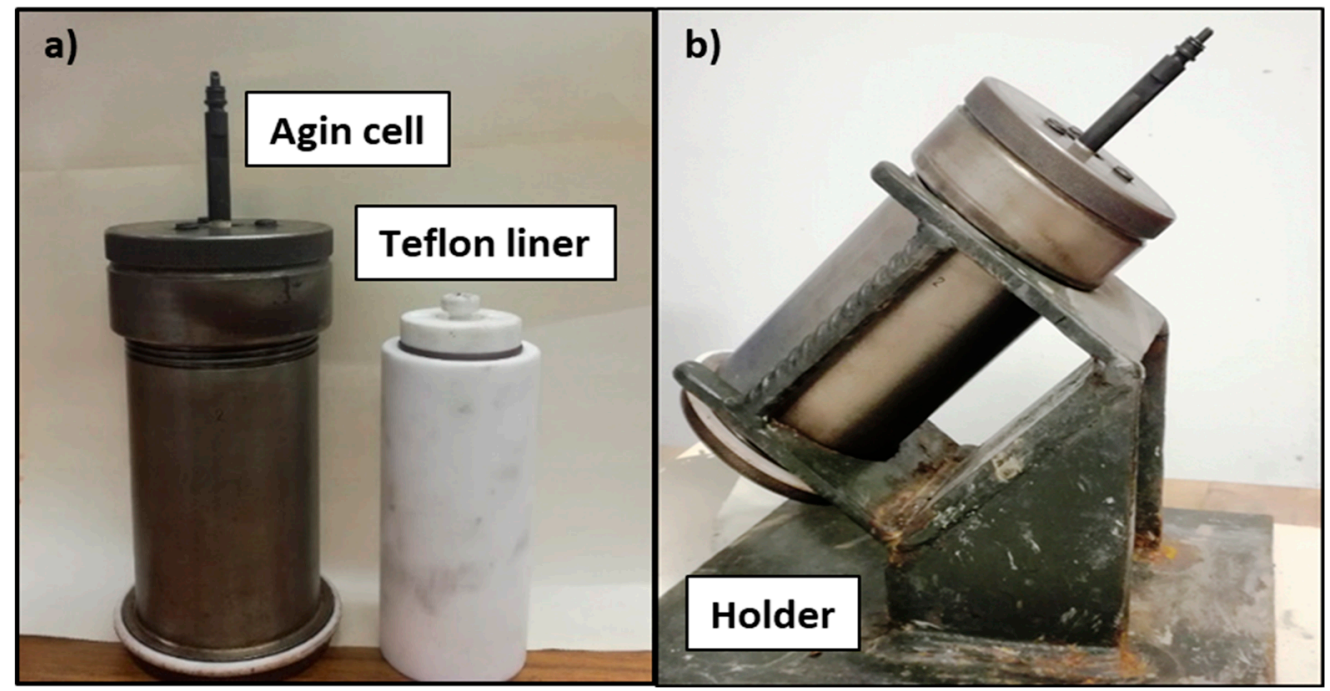

Figure 3. Experimental setup for static sag test: (a) vertical and (b) inclined $\left(45^{\circ}\right)$ [28].

The acceptable sag factor ranges between 0.50 to 0.53 , and higher than this range indicates solids settlement $[29,38]$.

Viscometer sag shoe test (VSST) was used to perform sag tests under dynamic conditions. The test was run for $30 \mathrm{~min}$ at $100 \mathrm{rpm}$ and $120^{\circ} \mathrm{F}$. The experimental procedure for the dynamic sag test is well described in previous studies [26,27]. VSST was calculated using Equation (2).

$$
V S S T=0.834\left(W_{2}-W_{1}\right)
$$

VSST is the dynamic sag factor in ppg, and $W_{1}$ and $W_{2}$ are the weight (in gram) of fluid samples $(10 \mathrm{~mL})$ taken from the cell before and after the test.

A VSST value that is equal to or less than one indicates that the fluid would exhibit acceptable sag performance [39]. Figure 4 shows the experimental setup for dynamic sag test, and Table 3 shows the experimental conditions for static and dynamic sag tests.

Table 3. Experimental conditions for sag test.

\begin{tabular}{ccc}
\hline Parameter & Static Sag Test & Dynamic Sag Test \\
\hline Temperature & $350^{\circ} \mathrm{F}$ & $120^{\circ} \mathrm{F}$ \\
Pressure & $500 \mathrm{psi}$ & Atmospheric pressure \\
Time & $24 \mathrm{hrs}$ & $30 \mathrm{~min}$ \\
Inclination & Vertical $/ 45^{\circ}$ & \\
\hline
\end{tabular}




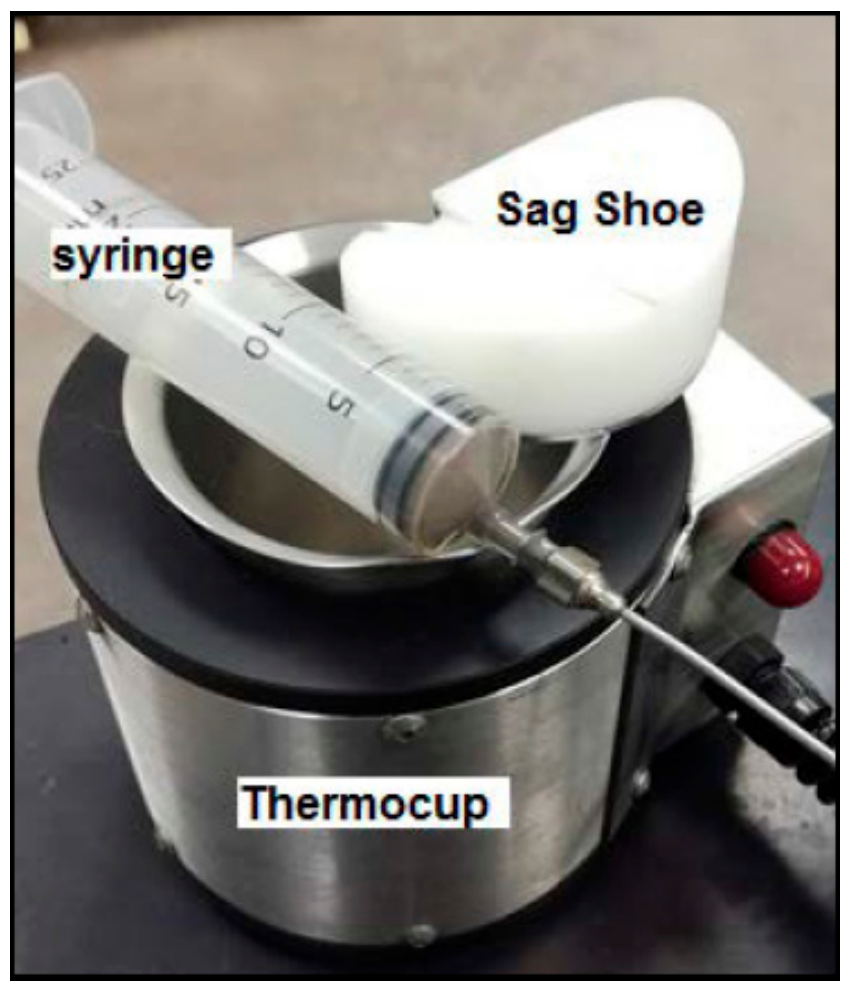

Figure 4. Experimental setup for dynamic sag test [26].

\subsection{Rheology Measurements}

After the drilling fluid preparation, the density and the electrical stability were measured for all the drilling fluid samples at room temperature using mud balance and emulsion stability tester, respectively. Rheological properties were obtained from the viscometer dial readings at $350^{\circ} \mathrm{F}$ and 2000 psi. These properties are plastic viscosity, yield point, and gel strength after $10 \mathrm{~s}, 10 \mathrm{~min}$, and $30 \mathrm{~min}$ of static gel time. The viscoelastic properties of the drilling fluid (storage modulus and loss modulus) were obtained from the oscillatory test conducted at $350^{\circ} \mathrm{F}$ using an Anton Paar rheometer. Storage modulus could be used as an indication of solids sag tendency [38].

\subsection{HPHT Filtration Test}

Filtration tests were conducted to study the impact of using the combined weighting material on the filtration performance, and the sealing properties of the resulted filter cake. The filtration test was conducted on a 10 -micron ceramic filter disc at $350^{\circ} \mathrm{F}$ temperature and 300 psi differential pressure. The test was run for $30 \mathrm{~min}$, and the fluid filtrate volume was recorded with time. Afterward, the properties of the formed filter cake were measured (weight and thickness). The filtration performance of the base fluid sample was compared with the performance of the drilling fluid sample with the combined weighting agent under the same experimental conditions.

\section{Results and Discussion}

Different drilling fluid samples were prepared by mixing ilmenite with barite in different concentrations (20,40,60, and $80 \mathrm{wt} . \%)$. After fluid preparation, density and electrical stability were measured for all drilling fluid samples. Figure 5 exhibits the impact of ilmenite concentration on fluid density and electrical stability. The density of the base drilling fluid was $14.5 \mathrm{ppg}$, and as the concentration of ilmenite increased, the drilling fluid density slightly increased to reach up to $15.2 \mathrm{ppg}$ for $100 \mathrm{wt}$.\% Ilmenite sample. This increase is due to the difference between ilmenite density $\left(4.79 \mathrm{~g} / \mathrm{cm}^{3}\right)$ and barite density $\left(4.48 \mathrm{~g} / \mathrm{cm}^{3}\right)$. Therefore, when adding ilmenite, less solids will be needed to attain the same density of the base fluid $[1,30]$. 


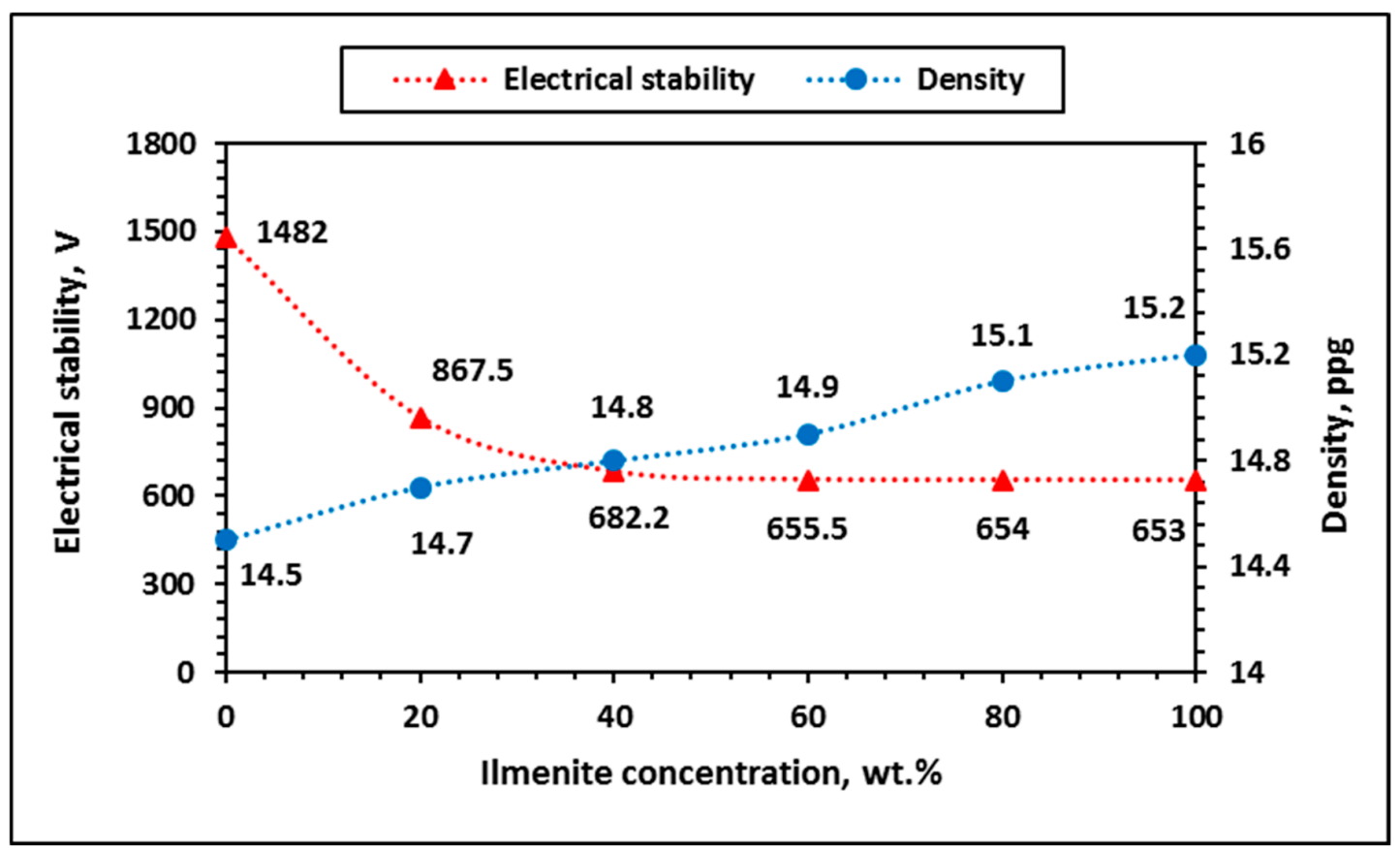

Figure 5. Effect of ilmenite concentration on drilling fluid density and electrical stability at room temperature.

In contrast, adding $40 \mathrm{wt} . \%$ ilmenite reduced the electrical stability, ES, of the base fluid from $1482 \mathrm{~V}$ to $682 \mathrm{~V}$, then it was stable at around $655 \mathrm{~V}$ for higher concentrations. The electrical stability is used as an indication of emulsion stability as it measures the voltage of the current flowing in the mud. Electrical stability is affected by many factors, such as viscosity, types and concentrations of solids, and emulsifiers. The observed reduction in electrical stability can be attributed to the value of ilmenite's electrical conductivity as it is much higher than barite conductivity, therefore, replacing barite with ilmenite will increase the conductivity of the drilling fluid, while previous studies reported that adding barite to invert emulsion increases the electrical stability of the drilling fluid [40]. However, this value is still above the acceptable value, $500 \mathrm{~V}$, according to oil industry practices, and it can be adjusted by optimizing drilling fluid additives, such as emulsifiers [41]. Moreover, field and laboratory studies confirmed that the electrical stability trend (with time) is the key property in mud stability, not its absolute value; higher ES values do not always mean good fluid stability [40].

Figures 6 and 7 show the impact of the combined weighting agent on solids sag tendency of invert emulsion drilling fluid under dynamic and static conditions at $120^{\circ} \mathrm{F}$ and $350{ }^{\circ} \mathrm{F}$, respectively. Under both dynamic and static conditions, the base drilling fluid (with $100 \mathrm{wt} . \%$ barite) exhibited poor sag performance with a sag factor of around 0.57 and 0.6 at vertical and inclined static conditions, respectively, and with a VSST value of 1.5 at dynamic conditions, therefore, solids settlement is likely to occur. The addition of ilmenite reduced sag tendency of the drilling fluid, and as the concentration of ilmenite increased, sag tendency was reduced. Only $40 \mathrm{wt} . \%$ ilmenite was enough to eliminate solids sag in both cases with sag factor and VSST of around 0.5. Higher concentration ( $>40 \mathrm{wt} . \%)$ is not required, and it will increase the cost of the drilling fluid. The static sag factor at an inclination of $45^{\circ}$ was slightly higher than at vertical conditions because solids settlement is accelerated at inclination between $30^{\circ}$ and $60^{\circ}$ [20,42]. The optimum ilmenite concentration, however, may vary with the used drilling fluid formulations and well conditions which require optimizing the ratio of ilmenite to barite for each formulation before field applications. The improvement of sag performance resulted from adding ilmenite to the drilling fluid can is attributed to the surface charge and the size of solid particles. Surface charge plays a vital role in the stability of colloidal systems that is governed by the repulsive force and attractive force between colloidal particles [43]. As reported in the previous studies, the surface charge of ilmenite particles dispersed in water ranges between -30 and $-35 \mathrm{mV}$ [9], while 
barite has a lower surface charge of around $-20 \mathrm{mV}$ [43]. The higher the surface charge, the more stable is the colloidal system, and a surface charge that is above $\pm 30 \mathrm{mV}$ is considered to have good colloidal stability [44]. Moreover, the difference in the particle size between barite and ilmenite $(17 \mu \mathrm{m}$ and $5 \mu \mathrm{m}$, respectively) has impact on the capability of the drilling fluid to suspend the weighting material. As the particle size decreases, the ratio of the surface area to the volume increases which increases drag and lift forces on the solid particles to overcome cohesion and gravitational forces and consequently prevents the settlement of solid particles [20].

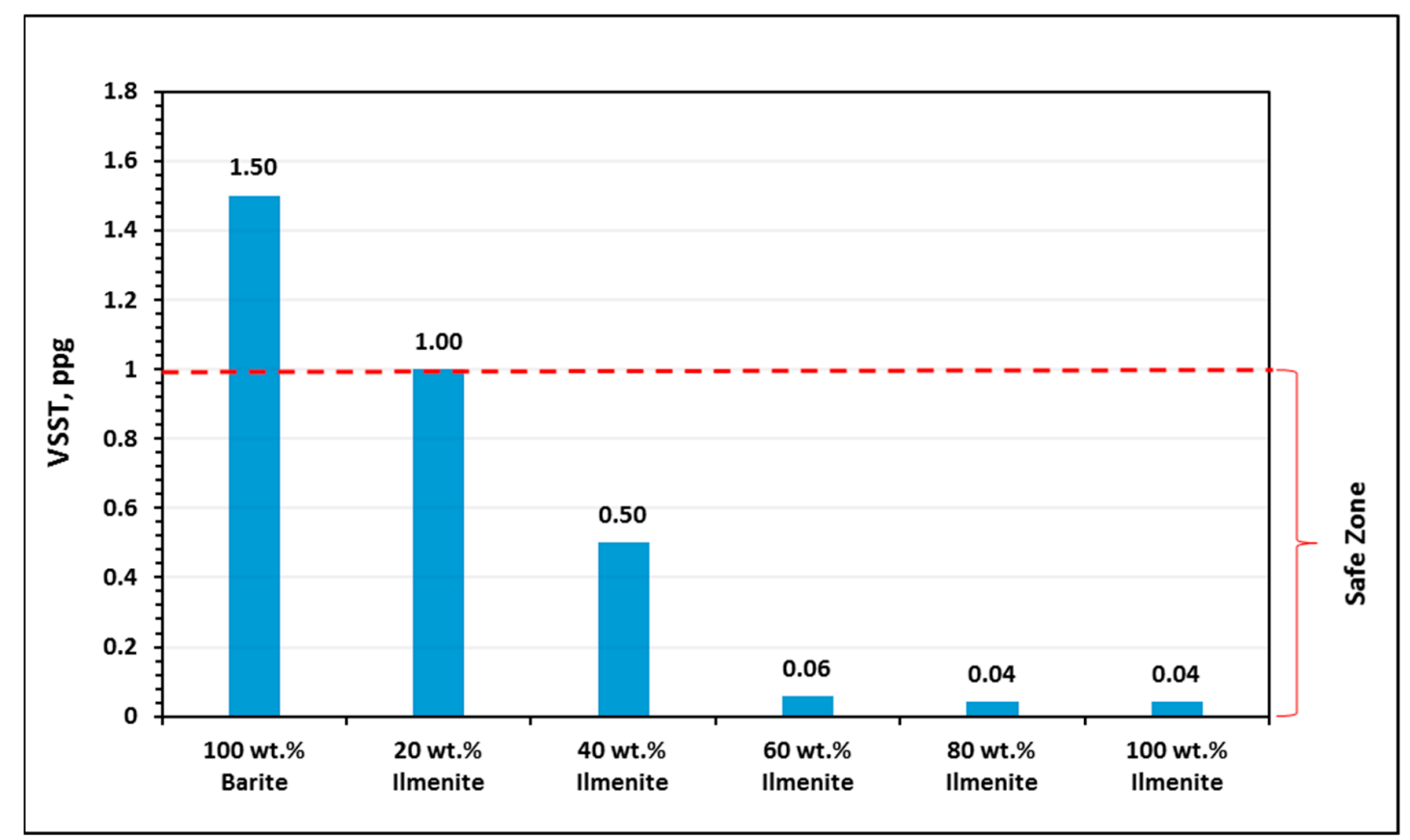

Figure 6. Effect of ilmenite on drilling fluid sag tendency at dynamic conditions $\left(120^{\circ} \mathrm{F}\right)$.

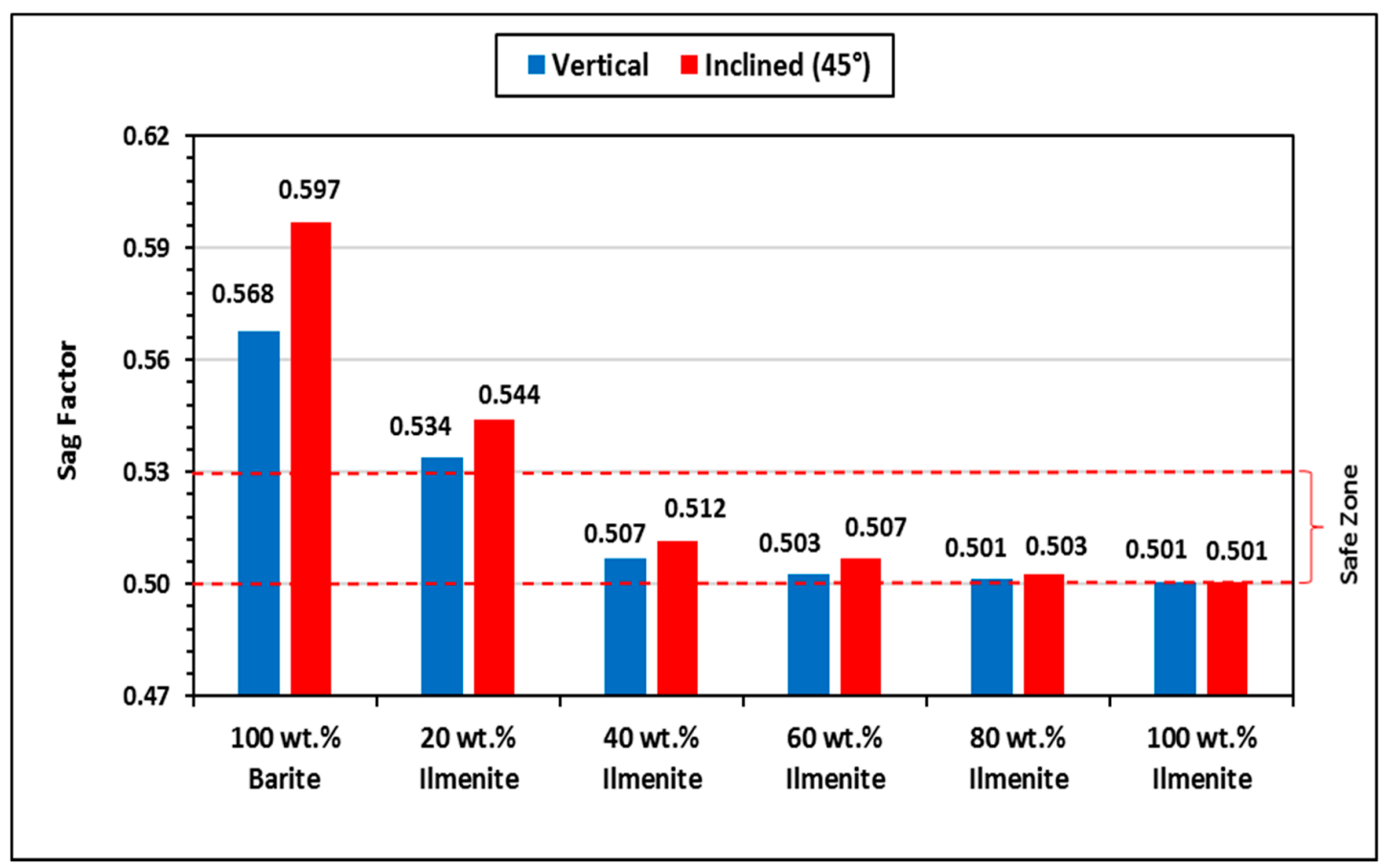

Figure 7. Effect of ilmenite concentration on sag tendency at static conditions $\left(350^{\circ} \mathrm{F}\right)$. 
Drilling fluid rheology was measured at $350^{\circ} \mathrm{F}$ to evaluate the effect of ilmenite concentration on the drilling fluid rheology at such elevated temperature. Figure 8 compares the rheological properties of $40 \mathrm{wt} . \%$ ilmenite fluid sample with the base fluid sample. Adding $40 \mathrm{wt} . \%$ ilmenite increased the yield point from 15 to $26 \mathrm{lb} / 100 \mathrm{ft}^{2}$ whereas, the plastic viscosity did not increase significantly, from 15 to $16 \mathrm{cP}$. Consequently, the yield point to plastic viscosity ratio (YP/PV) increased from 1.2 to 1.6, which indicates an enhancement in the drilling fluid stability and suspension capability of solid particles. The higher the YP/PV ratio, the more stable the drilling fluid [45]. In addition to barite sag, YP/PV ratio affects many drilling fluid parameters such as equivalent circulating density, hole cleaning, and surge and swap pressure [46]. Moreover, adding $40 \mathrm{wt} . \%$ ilmenite with barite improved the gel strength of the drilling fluid, and validated the results of the sag test. Figure 9 compares the viscoelastic properties of $40 \mathrm{wt} . \%$ ilmenite fluid sample with the base drilling fluid sample within the nonlinear viscoelastic range. From $G^{\prime \prime} / G^{\prime}$ ratios, the loss modulus $G$ " is lower than the storage modulus $G^{\prime}$ for both fluid samples, which indicates that the nonlinear viscoelastic range was dominated by the elastic behavior. Adding $40 \mathrm{wt} . \%$ ilmenite enhanced the elasticity of the drilling fluid by increasing the storage modulus; thus, more stable gel structure would result [47]. The increase in the yield point, gel strength, and the storage modulus values is because of the slight increase in the fluid density, from 14.5 to $14.8 \mathrm{ppg}$, resulted from adding ilmenite to the drilling fluid because as the density increases, the fluid resistance for initial flow increases [20].
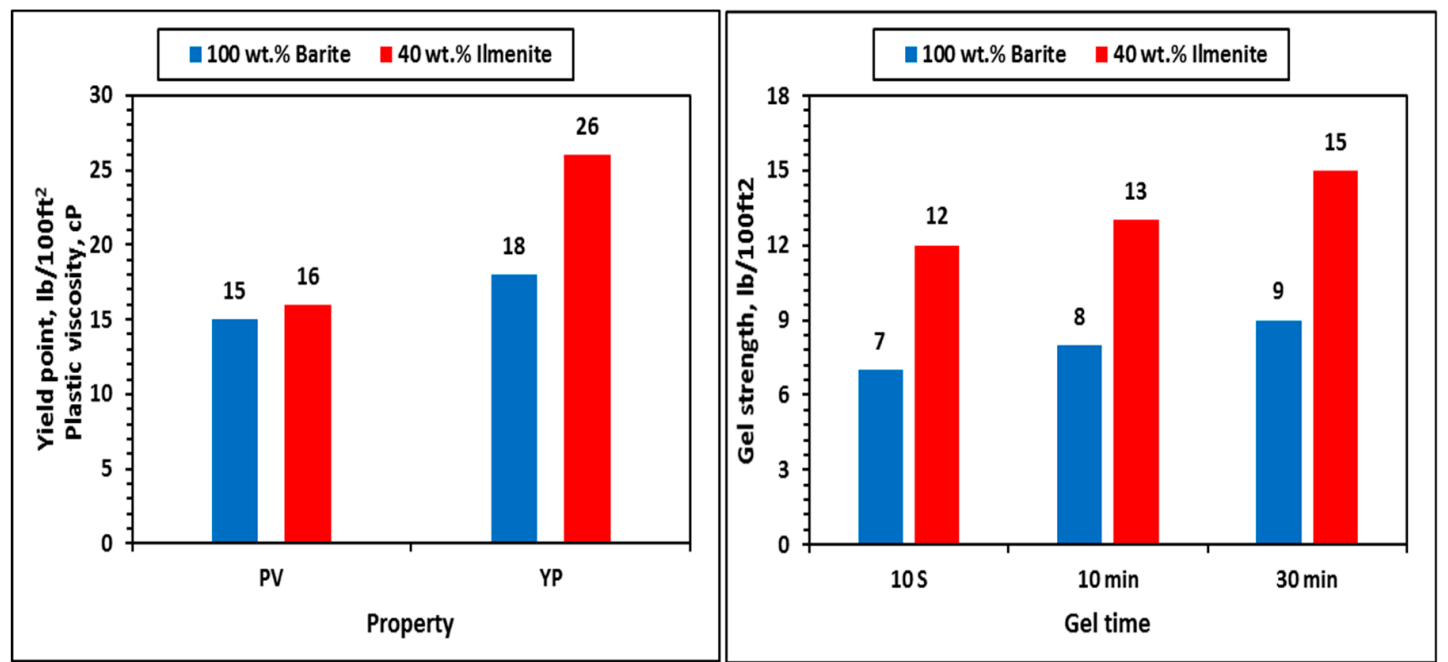

Figure 8. Effect of adding ilmenite on rheological properties $\left(350^{\circ} \mathrm{F}\right)$.
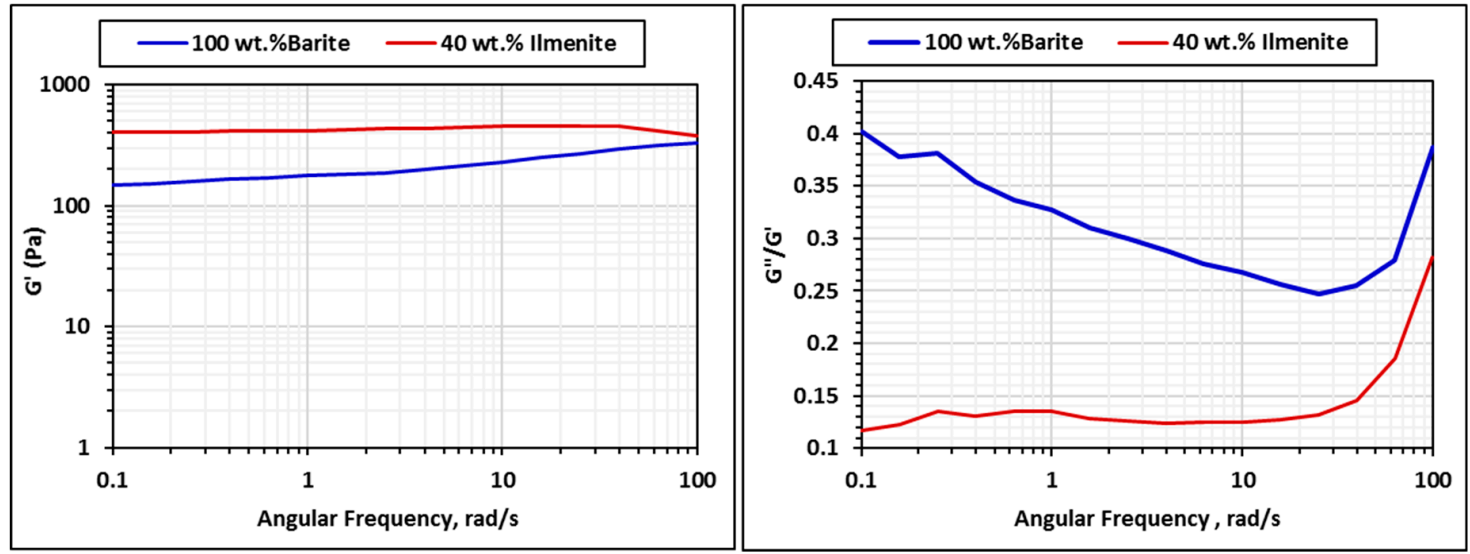

Figure 9. Effect of ilmenite on viscoelastic properties $\left(250^{\circ} \mathrm{F}\right)$.

Figure 10 compares the filtration performance of the $40 \mathrm{wt} . \%$ ilmenite sample with the base drilling fluid sample at $350^{\circ} \mathrm{F}$. As shown in Figure 9, adding $40 \mathrm{wt} . \%$ ilmenite slightly improved the filtration 
performance. The total fluid filtrate was reduced from $5.6 \mathrm{~cm}^{3}$ to $4.5 \mathrm{~cm}^{3}$, and the thickness of the filter cake was reduced from $2.92 \mathrm{~mm}$ to $1.93 \mathrm{~mm}$. This improvement in the filtration performance is because of the particle size distribution of the solid particles in the mud as it plays a vital role in the filtration performance and the sealing properties of the filter cake and this finding is supported by the previous studies [7,48-51]. The filtration test results are summarized in Table 4 . Despite the improvement in the filtration performance of the drilling fluid resulted from adding ilmenite to the drilling fluid, another challenge will be encountered when using this solution which is the removal of the formed filter cake after drilling operations because the filter cake adds a skin damage that reduces oil and gas production and affects the results of pressure transient tests [52,53]. It was addressed in some previous studies that the weighting material forms $70-90 \%$ of the filter cake mineralogy [13], so in this case, the formed filter cake consists mainly of barite and ilmenite. Consequently, the process of removing the composite filter cake will be more challenging as it requires a special fluid formulation that can efficiently dissolve both barite and ilmenite.

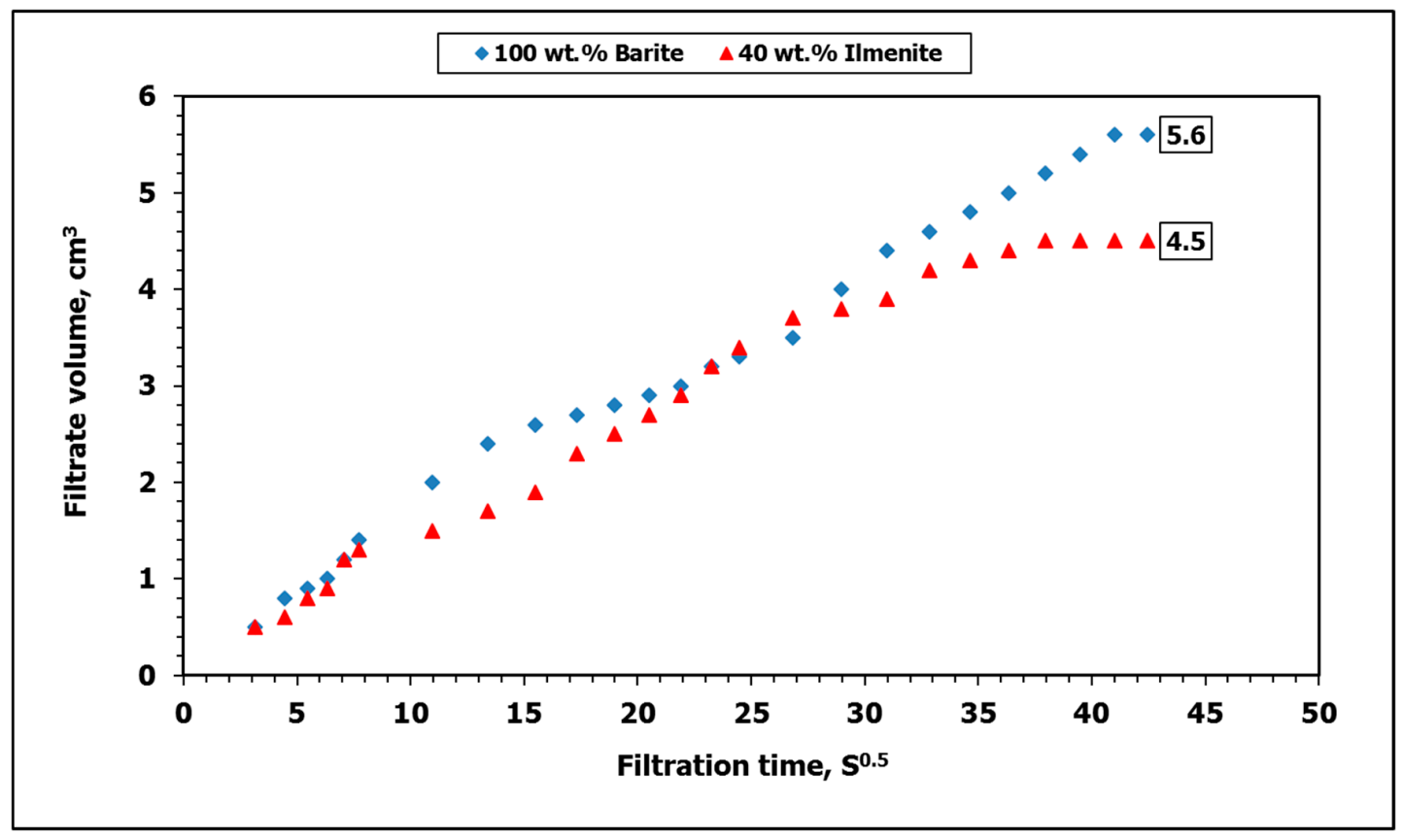

Figure 10. Effect of adding ilmenite on the filtration performance of the drilling fluid $\left(350^{\circ} \mathrm{F}\right)$.

Table 4. Summary for filtration test results.

\begin{tabular}{ccc}
\hline Parameter & 100 wt. $\%$ Barite & 40 wt. $\%$ Ilmenite \\
\hline Filtrate volume, $\mathrm{cm}^{3}$ & 5.6 & 4.5 \\
Filter cake thickness, $\mathrm{mm}$ & 2.92 & 1.93 \\
Filter cake weight, $\mathrm{g}$ & 13.6 & 11.9 \\
\hline
\end{tabular}

\section{Summary and Conclusions}

Experimental work was carried out to evaluate the mixture of barite and ilmenite as a solution to solids sag phenomenon while drilling high-pressure high-temperature wells with oil-based drilling fluids. Based on the findings of this study, the following conclusions can be drawn:

1. This study introduces a practical solution to barite sag issue in oil-based muds using a combined weighting material that comprises barite and ilmenite powders.

2. Adding ilmenite to barite-weighted oil-based mud slightly increased the drilling fluid density because ilmenite has a higher density than barite, whereas ilmenite reduced the electrical stability 
of the invert emulsion. However, it was within the acceptable value (above $500 \mathrm{~V}$ ), and it can be maintained by optimizing drilling fluid additives.

3. Ilmenite significantly reduced the sag factor under both static and dynamic conditions. Sag factor decreases as the concentration of ilmenite increases, and $40 \mathrm{wt} . \%$ ilmenite was adequate to eliminate barite sag in both conditions. Sag factor was reduced to 0.51 in static conditions, while VSST decreased from 1.5 to 0.5 at dynamic conditions.

4. Adding ilmenite enhanced the rheological and viscoelastic properties of the drilling fluid, which confirms sag test results.

5. A slight improvement in the filtration performance and the filter cake properties was observed with combined weighting material. Less fluid filtrate and filter cake thickness resulted. However, more research work is required to develop a fluid formulation that can effectively remove the composite filter cake.

6. The findings of this study confirmed that the proposed drilling fluid formulation could be used to drill HPHT wells efficiently without solids settlement. With this solution, different formulations of the drilling fluid with different properties and performance can be prepared depending on the purpose and well conditions. Additionally, mixing ilmenite with barite reduces the high cost of ilmenite-weighted fluids as only $40 \mathrm{wt} . \%$ ilmenite was found to be enough for sag prevention.

Author Contributions: Conceptualization, S.E. and S.B.; Methodology, S.B. and S.E.; Formal Analysis, A.M., S.E., and A.A.-M.; Investigation, A.M., S.B., and S.E.; Resources, S.E. and A.A.-M.; Data Curation, S.B.; Writing-Original Draft Preparation, A.M. and S.B.; Writing-Review \& Editing, A.M. and S.E.; Visualization, A.M. and S.B.; Supervision, S.E. and A.A.-M.; Project Administration, S.E.

Funding: This research received no external funding.

Acknowledgments: The authors wish to acknowledge King Fahd University of Petroleum and Minerals (KFUPM) for utilizing the various facilities in carrying out this research. Many thanks are due to the anonymous referees for their detailed and helpful comments. The authors wish to acknowledge Elkem company for providing the solid material (Ilmenite).

Conflicts of Interest: The authors declare no conflict of interest.

\section{References}

1. Caenn, R.; Darley, H.C.H.; Gray, G.R. Composition and Properties of Drilling and Completion Fluids, 6th ed.; Elsevier: Amsterdam, The Netherlands, 2011.

2. Hossain, M.; Al-Majed, A.A. Fundamentals of Sustainable Drilling Engineering; Scrivener Publishing LLC: Beverly, MA, USA, 2015.

3. Stroud, B.K. Mud-Laden Fluids and Tables on Specific Gravities and Collapsing Pressures; Louisiana Department of Conservation: Baton Rouge, LA, USA, 1922.

4. Stroud, B.K. Application of Mud-Laden Fluids to Oil or Gas Wells. U.S. Patent 1575945 A, 9 March 1926. Available online: https://patentimages.storage.googleapis.com/59/82/cc/ec8dc5d0f5687b/US1575945.pdf (accessed on 10 October 2019).

5. Fink, J.K. Petroleum Engineer's Guide to Oil Field Chemicals and Fluids; Gulf Professional Pub: Waltham, MA, USA, 2012.

6. Gordon, C.; Lewis, S.; Tonmukayakul, P. Rheological properties of cement spacer: Mixture effects. In Proceedings of the AADE Fluids Conference and Exhibition, Houston, TX, USA, 8-9 April 2008.

7. Mohamed, A.K.; Elkatatny, S.A.; Mahmoud, M.A.; Shawabkeh, R.A.; Al-Majed, A.A. The Evaluation of Micronized Barite as a Weighting Material for Completing HPHT Wells. In Proceedings of the SPE Middle East Oil \& Gas Show and Conference, Manama, Bahrain, 6-9 March 2017; Paper SPE-183768-MS.

8. Rugang, Y.; Guancheng, J.; Wei, L.; Tianqing, D.; Hongxia, Z. Effect of water-based drilling fluid components on filter cake structure. Powder Technol. 2014, 262, 51-61.

9. Elkatatny, S.M.; Nasr-El-Din, H.; Al-Bagoury, M. Evaluation of Micronized Ilmenite as Weighting Material in Water-Based Drilling Fluids for HPHT Applications. In Proceedings of the SPE Kuwait International Petroleum Conference and Exhibition, Kuwait City, Kuwait, 10-12 December 2013; Paper SPE 163377. 
10. Elkatatny, S.M.; Al Moajil, A.; Nasr-El-Din, H.A. Evaluation of a New Environmentally Friendly Treatment to Remove $\mathrm{Mn}_{3} \mathrm{O}_{4}$ Filter Cake. In Proceedings of the IADC/SPE Asia Pacific Drilling Technology Conference (APDT), Tianjin, China, 9-11 July 2012; Paper SPE 156451.

11. Al-Yami, A.S.; Nasr-El-Din, H.A.; Al-Majed, A.A.; Menouar, H. An Innovative Manganese Tetra-Oxide/KCl Water-Based Drill-in Fluids for HT/HP Wells. In Proceedings of the SPE Annual Technical Conference and Exhibition, Anaheim, CA, USA, 11-14 November 2007; Paper SPE-110638.

12. Tehrani, A.; Cliffe, A.; Hodder, M.H.; Young, S.; Lee, J.; Stark, J.; Seale, S. Alternative Drilling Fluid Weighting Agents: A Comprehensive Study on Ilmenite and Hematite. In Proceedings of the IADC/SPE Drilling Conference and Exhibition, Fort Worth, TX, USA, 4-6 March 2014; Paper IADC/SPE-167937.

13. Ba geri, B.S.; Mahmoud, M.; Abdulraheem, A.; Al-Mutairi, S.H.; Elkatatny, S.M.; Shawabkeh, R.A. Single stage filter cake removal of barite weighted water-based drilling fluid. J. Pet. Sci. Eng. 2017, 149, 476-484. [CrossRef]

14. Nguyen, T.; Miska, S.; Yu, M.; Takach, N. Predicting Dynamic Barite Sag in Newtonian-Oil Based Drilling Fluids in Pipe. In Proceedings of the SPE Annual Technical Conference and Exhibition, New Orleans, LA, USA, 4-7 October 2009; Paper SPE-124137.

15. Pozebon, D.; Lima, E.C.; Maia, S.M.; Fachel, J.M.G. Heavy metals contribution of non-aqueous fluids used in offshore oil drilling. Fuel 2005, 84, 53-61. [CrossRef]

16. Bern, P.A.; Oort, E.V.; Neustadt, B.; Ebeltoft, H.; Zurdo, C.; Zamora, M.; Slater, K.S. Barite Sag: Measurement, Modeling, and Management. SPE Drill. Completion 2000, 15, 25-30. [CrossRef]

17. Omland, T.H.; Saasen, A.; Zwaag, C.; Amundsen, P.A. The Effect of Weighting Material Sag on Drilling Operation Efficiency. In Proceedings of the SPE Asia Pacific Oil \& Gas Conference and Exhibition, Jakarta, Indonesia, 30 October-1 November 2007; Paper SPE 110537.

18. Saasen, A.; Jordal, O.H.; Burkhead, D.; Berg, P.C.; Løklingholm, G.; Pedersen, E.S.; Turner, J.; Harris, M.J. Drilling HT/HP Wells Using a Cesium Formate Based Drilling Fluid. In Proceedings of the IADC/SPE Drilling Conference, Dallas, TX, USA, 26-28 February 2002; Paper IADC/SPE 74541.

19. Zamora, M.; Bell, R. Improved Wellsite Test for Monitoring Barite Sag. In Proceedings of the AADE 2004 Drilling Fluids Conference, Houston, TX, USA, 6-7 April 2004; Paper AADE-04DF-HO-19.

20. Boyou, N.V.; Ismail, I.; Wan Sulaiman, W.R.; Sharifi Haddad, A.; Husein, N.; Hui, H.T.; Nadaraja, K. Experimental investigation of hole cleaning in directional drilling by using nano-enhanced water-based drilling fluids. J. Pet. Sci. Eng. 2019, 176, 220-231. [CrossRef]

21. Murphy, R.; Jamison, D.; Hemphill, T.; Bell, S.; Albrecht, C. Measuring and Predicting Dynamic Sag. SPE Drill. Completion 2008, 23, 142-149. [CrossRef]

22. Scott, P.D.; Zamora, M.; Aldea, C. Barite-Sag Management: Challenges, Strategies, Opportunities. In Proceedings of the IADC/SPE Drilling Conference, Dallas, TX, USA, 2-4 March 2004; Paper IADC/SPE 87136.

23. Basfar, S.; Mohamed, A.; Elkatatny, S.; Al-Majed, A. A combined barite-ilmenite weighting material to prevent barite sag in water-based drilling fluid. Materials 2019, 12, 1-13. [CrossRef] [PubMed]

24. Temple, C.; Paterson, F.; Leith, D. Method for Reducing Sag in Drilling, Completion, and Workover Fluids. Patent No. WO 2004/113467 A1, 29 December 2004.

25. Davis, L.; Lfvanec, W.; Shumway, W. Additive to enhance sag stability of drilling fluid. Patent No. WO 2017/188946 Al, 2 November 2017.

26. Basfar, S.; Elkatatny, S.; Mahmoud, M.; Kamal, M.S.; Murtaza, M.; Stanitzek, T. Prevention of Barite Sagging while Drilling High-Pressure High-Temperature (HPHT) Wells. In Proceedings of the SPE Kingdom of Saudi Arabia Annual Technical Symposium and Exhibition, Dammam, Saudi Arabia, 23-26 April 2018; Paper SPE-192198-MS.

27. Elkatatny, S.M. Enhancing the Stability of Invert Emulsion Drilling Fluid for Drilling in High-Pressure High-Temperature Conditions. Energies 2018, 11, 2393. [CrossRef]

28. Elkatatny, S.M. Mitigation of barite sagging during the drilling of high-pressure high-temperature wells using an invert emulsion drilling fluid. Powder Technol. 2019, 352, 325-330. [CrossRef]

29. Alabdullatif, Z.; Al-Yami, A.; Wagle, V.; Bubshait, A.; Al-Safran, A. Development of New Kill Fluids with Minimum Sagging Problems for High Pressure Jilh Formation in Saudi Arabia. Saudi Aramco J. Technol. (Spring) 2015. Available online: https://pdfs.semanticscholar.org/e36c/025ca72b5cc71c68ed8ff07a6106b12ae60e.pdf (accessed on 18 July 2018). 
30. Abdou, M.I.; Al-Sabagh, A.M.; Ahmed, H.E.S.; Fadl, A.M. Impact of barite and ilmenite mixture on enhancing the drilling mud weight. Egypt. J. Pet. 2018, 27, 955-967. [CrossRef]

31. Sharma, M.M.; Zhang, R.; Chenevert, M.E.; Ji, L.; Guo, Q.; Friedheim, J. A new family of nanoparticle based drilling fluids. In Proceedings of the SPE Annual Technical Conference and Exhibition, San Antoio, TX, USA, 8-10 October 2012; Paper SPE 160045.

32. Rafati, R.; Smith, S.R.; Haddad, A.S.; Novara, R.; Hamidi, H. Effect of nanoparticles on the modifications of drilling fluids properties: A review of recent advances. J. Pet. Sci. Eng. 2018, 161, 61-76. [CrossRef]

33. Smith, R.S.; Rafati, R.; Haddad, A.S.; Cooper, A.; Hamidi, H. Application of aluminium oxide nanoparticles to enhance rheological and filtration properties of water based muds at HPHT conditions. Colloids Surf. A 2018, 537, 361-371. [CrossRef]

34. Blomberg, N.; Melberg, B.; Boe, A.; Jacobsen, E.; Aarrestad, S. Evaluation of Ilmenite as Weight Material in Drilling Fluids. J. Pet. Technol. 2007, 36, 969-974. [CrossRef]

35. Haaland, E.; Pettersen, G.; Tuntland, O.B. Testing of Iron Oxides as Weight Materials for Drilling Muds. Paper SPE 6218. 1976. Available online: https://www.onepetro.org/general/SPE-6218-MS (accessed on 25 July 2019).

36. Tuntland, O.B.; Herfjord, H.J.; Lehne, K.A.; Haaland, E. Iron oxide as Weight Materials for Drilling Muds. Erdoel-Erdgas Z 1981, 97, 300-302.

37. Xiao, J.; Nasr-El-Din, H.A.; Al-Bagoury, M. Evaluation of Micronized Ilmenite as a Weighting Material in Oil-based Drilling Fluids for HPHT Applications. In Proceedings of the SPE European Formation Damage Conference and Exhibition, Noordwijk, The Netherlands, 5-7 June 2013; Paper SPE-165184.

38. Maxey, J. Rheological Analysis of Static and Dynamic Sag in Drilling Fluids. Annu. Trans. Nord. Rheol. Soc. 2007, 15, 181-188.

39. Aldea, C.; Growcock, F.B.; Lee, L.J.; Friedheim, J.E.; Oort, E.V. Prevention of Dynamic Sag in Deepwater Invert Emulsion Fluids. In Proceedings of the AADE 2001 National Drilling Conference, 'Drilling Technology', Houston, TX, USA, 27-29 March 2001.

40. Growcock, F.; Ellis, C.; Schmidt, D.; Azar, J. Electrical Stability, Emulsion Stability, and Wettability of Invert Oil-Based Muds. Spe Drill. Completion 1994, 9, 39-46. [CrossRef]

41. Van Zanten, R.; Miller, J.J.; Baker, C. Improved Stability of Invert Emulsion Fluids. In Proceedings of the IADC/SPE Drilling Conference and Exhibition, San Diego, CA, USA, 6-8 March 2012; Paper IADC/SPE 151404.

42. Skalle, P.; Backe, K.R.; Lyomov, S.K.; Sveen, J. Barite Segregation in Inclined Boreholes. J. Can. Pet. Technol. 1999, 38, 1-6. [CrossRef]

43. Bokern, D.G.; Hunter, K.A.; McGrath, K.M. Charged Barite-Aqueous Solution Interface: Surface Potential and Atomically Resolved Visualization. Langmuir 2003, 19, 10019-10027. [CrossRef]

44. Joseph, E.; Singhvi, G. Multifunctional nanocrystals for cancer therapy: A potential nanocarrier. Nanomater. Drug Deliv. Ther. 2019, 2019, 91-116. [CrossRef]

45. Chilingarian, G.; Alp, E.; Caenn, R.; Al-Salem, M.; Uslu, S.; Gonzales, S.; Dorovi, R.J. Mathur, R.M.; Yen, T.F. Drilling Fluid Evaluation Using Yield Point-Plastic Viscosity Correlation. Energy Sources 1986, 8, 233-244. [CrossRef]

46. Power, D.; Zamora, M. Drilling Fluid Yield Stress: Measurement Techniques for Improved Understanding of Critical Drilling Fluid Parameters. In Proceedings of the AADE National Technology Conference, Houston, TX, USA, 1-3 April 2003; Paper AADE-03-NTCE-35.

47. Bui, B.; Saasen, A.; Maxey, J.; Ozbayoglu, M.E.; Miska, S.Z.; Yu, M.; Takach, N.E. Viscoelastic Properties of Oil-Based Drilling fluids. Annu. Trans. Nord. Soc. 2012, 20, 33-47.

48. Bageri, B.S.; Benaafi, M.; Mahmoud, M.; Patil, S.; Mohamed, A.; Elkatatny, S. Effect of Arenite, Calcareous, Argillaceous, and Ferruginous Sandstone Cuttings on Filter Cake and Drilling Fluid Properties in Horizontal Wells. Geofluids 2019, 2019, 10. [CrossRef]

49. Bageri, B.S.; Mahmoud, M.; Elkatatny, S.; Patil, S.; Benaafi, M.; Mohamed, A. Effect of Drill Cuttings Mechanical Properties on Filter Cake Properties and Mud-Filtrate Invasion. In Proceedings of the 53rd US Rock Mechanics/Geomechanics Symposium, New York, NA, USA, 23-26 June 2019; Paper ARMA 19-1662.

50. Suri, A.; Sharma, M. Strategies for Sizing Particles in Drilling and Completion Fluids. In Proceedings of the European Formation Damage Conference, The Hague, The Netherlands, 21-22 May 2001; Paper SPE 68964.

51. Tuttle, R.N.; Barkman, J.H. New Nondamaging and Acid-Degradable Drilling and Completion Fluids. J. Pet. Technol. 1974, 26, 1221-1226. [CrossRef] 
52. Dejam, M.; Hassanzadeh, H.; Chen, Z. Semi-Analytical Solutions for a Partially Penetrated Well with Wellbore Storage and Skin Effects in a Double-Porosity System with a Gas Cap. Transp. Porous Media 2013, 100, $159-192$. [CrossRef]

53. Dejam, M.; Hassanzadeh, H.; Chen, Z. Semi-analytical solution for pressure transient analysis of a hydraulically fractured vertical well in a bounded dual-porosity reservoir. J. Hydrol. 2018, 565, 289-301. [CrossRef]

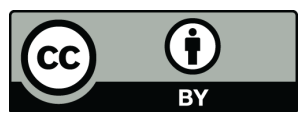

(C) 2019 by the authors. Licensee MDPI, Basel, Switzerland. This article is an open access article distributed under the terms and conditions of the Creative Commons Attribution (CC BY) license (http://creativecommons.org/licenses/by/4.0/). 